\title{
THE CENTRALITY OF "FRINGE HISTORY": DIASPORA, THE INTERNET AND A NEW VERSION OF VIETNAMESE PREHISTORY
}

\author{
Liam C. Kelley* \\ Institute of Asian Studies, Universiti Brunei Darussalam, \\ Jalan Tunku Link, Gadong, BE1410, Brunei \\ E-mail: liam.kelley@ubd.edu.bn
}

Published online: 30 January 2020

To cite this article: Kelley, L. C. 2020. The centrality of "fringe history": Diaspora, the Internet and a new version of Vietnamese prehistory. International Journal of Asia Pacific Studies 16 (1): 71-104, https://doi.org/10.21315/ijaps2020.16.1.3

To link to this article: https://doi.org/10.21315/ijaps2020.16.1.3

\begin{abstract}
Until recently, virtually all information about the past in Vietnam was produced by scholars working for the state, mainly university professors, and published in print media. In recent years, however, private individuals have begun to make use of the Internet to offer new perspectives on the Vietnamese past, and in some cases to print their work. Some of these amateur historians have now produced a new narrative about Vietnamese prehistory. This narrative presents an extremely positive view of the history of the ancient ancestors of the Vietnamese, seeing them as essentially the founders of East Asian civilisation. While some aspects of this narrative were first proposed by South Vietnamese philosopher Luong Kim Địh in the 1960s, amateur Vietnamese historians in the diaspora around the turn of the 21st century added what they argued were "scientific" findings of "international" scholars to this narrative. Finally, scholars in Vietnam accessed these ideas through the Internet and synthesised them with the works of scholars working in Vietnam. This spread of ideas from South Vietnam into the diaspora and then back to Vietnam via the Internet offers a fascinating insight into the ways in which communication in the Digital Age has enabled some authors from the previously divided worlds of Vietnam and the diaspora to find common ground to promote a nationalistic vision of the distant past
\end{abstract}


out of a shared desire to create a strong cultural and philosophical foundation that will enable Vietnamese to thrive in the global age.

Keywords: Vietnamese prehistory, Vietnamese diaspora, Lương Kim Định, Cung Đình Thanh, Hà Văn Thùy

\section{INTRODUCTION}

On 14 July 2012, a symposium was held at the Temple of Literature in Hanoi to commemorate the 15th anniversary of the passing of South Vietnamese philosopher Lương Kim Định. ${ }^{1}$ Organised by the Centre for Enlightened Wisdom (Trung tâm Minh triết) and the Centre for Philosophical Studies of the Orient (Lý học Đông phương), and including guests of honour from the Communist Party, the National Assembly and academia, this was the first event ever held in the Socialist Republic of Vietnam to discuss Lương Kim Định's writings and ideas. After the opening ceremony, this symposium commenced with a presentation by public figure Hà Văn Thùy who stated that:

From a half a century ago, Kim Định declared with the clairvoyance of a prophet that the Việt people occupied the territory of the Middle Kingdom before the Chinese and established a culture of Việt Confucian [Việt Nho] humanism and enlightened wisdom. Sharing the same fate as other prophets, for the past 50 years Kim Định has been dismissed and criticized! However, now time and science offer Kim Định proof. His theories of Việt Confucianism and Tranquillity Philosophy [An Vi] have become treasures that not only help the Việt people rediscover their original selves so that they can renew the Vietnamese nation, but also that light the torch of enlightened wisdom so that it can shine on humanity (Vũ 2012).

For anyone outside of Vietnam who has studied Vietnamese history through mainstream academic channels, the ideas expressed here that the ancestors of the Vietnamese occupied the area of what is today China and established a cultural foundation that can now serve as a guide for humankind are ones that will not be familiar. Whether one has read premodern Vietnamese chronicles that begin by tracing a line of political descent in antiquity from the mythical ancient Chinese ruler, Shennong, to the mythical Vietnamese rulers, the Hùng Kings, or colonial-era scholarship by French historians who argued that true history began in the area of what is today Vietnam with the advent of Chinese rule in the late second century $\mathrm{BCE}$, or even nationalist scholarship from 
North Vietnam in the 1960s and 1970s that sought to demonstrate that there was a sophisticated society in the Red River Delta prior to contact with the Chinese, or the works of American historian Keith Taylor whose ideas have transformed from following the Vietnamese nationalist perspective to arguing that there is too little evidence to state with certainty about the distant past, in none of these works is the claim made that the distant ancestors of the Vietnamese had occupied the area of what is today China and established the foundation of what we can think of as the East Asian cultural tradition (Ngô 1983 [1479]; Maybon and Russier 1909; Ủy ban khoa học xã hội Việt Nam 1971; Taylor 1983, 2013).

However, anyone who has spent time in Vietnam in the past 20 years, or who reads online postings on Vietnamese history, is likely to have encountered the above ideas. As a researcher of Vietnamese history, I began to come across ideas like these starting in the early 2000s. Whether it be from questions asked at professional talks, to casual conversations in cafes, I repeatedly encountered ideas that were not part of the academic training that I had received, but which were clearly part of Vietnamese popular historical knowledge, and which were definitely important for certain Vietnamese, both within Vietnam and overseas.

The topics of this "alternative history" that I encountered the most focused mainly on prehistory and the formation of traditional Vietnamese culture. To give some examples, I was told that the Vietnamese had created a written script (now lost) before literary Chinese was adopted by members of the elite some 2,000 years ago. I was also told that the Vietnamese created the Classic of Changes (Yijing) - a text that most scholars around the world would consider one of the earliest "Chinese" texts - and that the Chinese later "stole" it, claiming it as their own. Indeed, over time I heard people say much more along these lines, informing me for instance, and as Hà Văn Thùy stated earlier, that the Vietnamese inhabited the area of China before the Chinese did, and that there was a fundamental division between these two peoples, with the Vietnamese being "agriculturists" and the Chinese being "pastoralists." Finally, I was also told numerous times that rice cultivation had been invented by the Vietnamese, and that this had been "proven" by a Western scholar in a book called East of Eden.

The more I heard people make such comments, the more curious I was to know where these ideas came from. I therefore started looking, and ultimately came to realise that many of these ideas were first promoted by a philosopher by the name of Lương Kim Định who was very active in South Vietnam in the 1960s and early 1970s. Scholars from South Vietnam were not welcomed 
by the Communist Vietnamese government when the Vietnam War ended in 1975, and Lương Kim Định was no exception. He migrated to America and his books were banned. How then, I wondered, could it be that his ideas were known and were circulating in 21st century Vietnam? And how is it that an official symposium was held, at the Temple of Literature in the heart of Hanoi, in 2012 to discuss his ideas?

Such questions lead to numerous complex issues that are beyond the scope of this essay. Ultimately, however, we can say that there is a common thread that ties together the ideas of Lương Kim Định, Hà Văn Thùy and many others, and that is a sense that forces such as Westernisation, and now globalisation, pose an existential threat to Vietnamese society, and that a new Vietnamese philosophy and culture needs to be created in order to withstand that threat. Further, to one degree or another, the individuals discussed in this article also all hold that a Communist government, or the current establishment intellectuals, are incapable of doing this. Lương Kim Định, for instance, sought in the 1960s to produce a philosophy for South Vietnam that would counter Western influence and that would also serve as an alternative to Communism. Cung Đình Thanh, a key figure in the development of the ideas examined in this article whom we will meet in the subsequent section, believed in the 1990s from his vantage point in Australia that Communist rule would soon come to an end in Vietnam and that the country would need a new culture for a new age, but one that was still deeply rooted in something identifiably "Vietnamese." At that time the government in Vietnam saw globalisation as a threat and was seeking to counter the anticipated negative impact that Vietnam's integration into the world would bring to Vietnamese culture and society by promoting various aspects of traditional culture. However, as we will see below, Hà Văn Thùy wrote in 2005 that although the government had issued numerous resolutions "to protect the cultural essence of the nation" (bảo vệ bản sắc văn hóa dân tộc), these resolutions, he argued, had not been effective. Hence the need, he also argued, for others to take responsibility to produce a new culture, that could withstand the "cultural invasion" (xâm lăng văn hóa) of global influences (Hà 2005).

The individuals discussed in this article therefore were all concerned about the ability of Vietnamese culture and society to survive its contact with foreign cultures. Further, they all felt that the first step toward strengthening Vietnamese culture and society was by offering a new perspective on the earliest periods of history. This article is meant to serve as an initial effort to map out the ideas of this group of concerned individuals regarding that distant past, or what is essentially Vietnamese prehistory. The historical ideas that 
they have developed serve as the context from which they discuss ideas that can serve as a new culture and philosophy for the Vietnamese. Lương Kim Định, for instance, developed certain philosophical theories, such as "Việt Confucianism" and "Tranquillity Philosophy" that are based on the belief that ideas in works like the Classic of Changes were first developed by the ancestors of the Vietnamese. To establish this point, Lương Kim Định developed a unique version of prehistory that argued that the ancestors of the Vietnamese were the first inhabitants of the Asian mainland and that they created the foundation of what people today would refer to as traditional "Chinese" or "East Asian" culture. In the past 30 years, Vietnamese in the diaspora and in Vietnam have developed that story of prehistory further by incorporating ideas from archaeology and genetic science. They have been able to do this in large part because the Internet has made both information available and has facilitated communication between Vietnamese in the diaspora and in Vietnam who were previously more isolated from each other. This essay will trace the development of these ideas between members of these different societies.

While the ideas that make up this alternative story of Vietnamese prehistory have travelled from South Vietnam, to the diaspora, and now back into Vietnamese consciousness via the Internet and through the efforts of both overseas Vietnamese and Vietnamese in country, the individuals who have contributed to developing these historical ideas can largely be categorised as occupying a place on the "fringes" of Vietnamese academic life, or certainly on the fringes of the historical profession. Indeed, the same classification applied to Lương Kim Định as well when he was active in South Vietnam (Tạ 2008). At the same time, the individuals discussed in this article, particularly those writing in the 1990s and 2000s, have also been critical of the establishment scholars at the centre of official academic life in Vietnam. This can be seen in a couple of ways. First, some of these authors contrast what is supposedly known by "international scholars" with what establishment scholars in Vietnam have written, and essentially ridicule scholars in Vietnam for not being up to date. However, as we will see in the subsequent discussion, there are serious issues with how these writers understand and make use of "international scholarship." Second, these writers take a key element of modern nationalist scholarship in Vietnam - the critique of the supposed Sino-centric approach of colonialera scholars - and likewise criticise establishment scholars in Vietnam for not moving far enough beyond that paradigm by not recognising the "Vietnamese" contribution to the origins of East Asian civilisation. However, as we will also see below, while arguing that the ancestors of the Vietnamese are the founders of various aspects of East Asian civilisation does indeed move far beyond the 
colonial-era perspective of seeing Vietnam as a "Little China," the evidence for this argument is extremely problematic.

As such, while this "alternative history" is not based on solid evidence, it is firmly grounded in contemporary social dynamics, and it is able to flourish in part because of those dynamics. While some of the authors discussed in this article are openly critical of establishment historians, there has been very little response from professional historians. It may be the case that establishment scholars do not see the need to respond to non-professional historians, but the fact that the writers discussed in this article are active on the Internet whereas establishment historians are not means that these new ideas about Vietnamese prehistory are able to persist and to play an increasingly central role in Vietnamese life today. As such, I refer to the story of Vietnamese prehistory that these authors have created as "fringe history" to denote that it has emerged outside of the world of professional historians. However, the fact that these ideas are now discussed in such central locations as the Temple of Literature points to the "centrality" of this "fringe history" in the lives of some Vietnamese today.

In this paper, we will trace the journey that these ideas that make up this "fringe history" have taken. It is a story of how ideas from the "fringes" of the historical profession have gradually come to enjoy a position of "centrality" among some segments of Vietnamese society today. We begin with the writings of Lương Kim Định.

\section{LƯƠNG KIM ĐỊNH}

Born in 1914 in Nam Định Province in northern Vietnam, Kim Định, as he is commonly referred to, became a Catholic priest and then in the late 1940s journeyed to France where he spent the next decade obtaining degrees in philosophy and Sinology. Kim Định then returned to Vietnam where he worked in various universities in the South in the 1960s and early 1970s before moving to America at the end of the war. During this period when Kim Định was working in South Vietnam, he published extensively ("Lương Kim Định" n.d.).

The works that Kim Định wrote were not strictly speaking histories, but they contained a great deal of historical information, and Kim Định sought to educate his readers about the past. What he himself attempted to produce was a new philosophy. Writing in the 1960s and early 1970s, Kim Định feared that the materialism of the West and the Marxism of North Vietnam could both 
overwhelm South Vietnamese society if an appropriate philosophy for the country was not developed. In creating a new philosophy, Kim Định sought to find a way to embrace Western logic while still maintaining aspects of traditional culture. To simplify a complex argument that was developed over a series of publications, Kim Định did this first by arguing that East Asian culture did contain logical, scientific ideas. He noted, for instance, that such ideas can be found in the Classic of Changes, one of the oldest texts in East Asia and a foundational work for East Asian philosophy.

This idea that one can find logic in the Classic of Changes was first promoted in the early 20th century by the Chinese reformist intellectual and educator $\mathrm{Hu}$ Shi and was subsequently promoted by many intellectuals in East Asia. However, Kim Định brought a novel interpretation to this discussion by arguing that the Classic of Changes had been created by the ancestors of the Vietnamese. To make this point, Kim Định creatively employed concepts from the new field of structural anthropology to argue that early Vietnamese texts revealed a structure of meaning that replicated concepts in the Classic of Changes (Lương 1973). Without providing evidence, he also argued that this was because it was the ancestors of the Vietnamese who had created the Classic of Changes as they were the first inhabitants of the Asian mainland and that later "pastoralist" Han Chinese drove the "agriculturalist" Vietnamese southward until they eventually reached the Red River Delta. In the process, the Chinese appropriated the Classic of Changes and claimed it as their own and as part of the "Confucian" tradition (Lương 1970: 51-63).

While Kim Định creatively employed ideas from structural anthropology to make such arguments, he also developed a concept of his own called "obscure history" (huyền sü). The first Vietnamese written records about antiquity were not recorded until the 15th century CE and contained information that premodern scholars viewed as "absurd" and which French colonial scholars likewise dismissed as "myth." To Kim Định, however, these accounts represented a kind of "obscure history" that combined both poetic exaggeration with actual historical documentation and which the historian could interpretively tease meaning from (Lương 1970: 26-36).

Kim Định's ideas were inspiring to some Vietnamese, but they were difficult to document, particularly his arguments that the ancestors of the Vietnamese were the first to inhabit the Asian mainland, that they were agriculturalists before the Han Chinese, that they created the Classic of Changes, and that they were pushed southward to the Red River Delta by invading Han Chinese pastoralists. These were also issues that Vietnamese in Vietnam likely did not think much about after 1975 as Kim Định’s books 
were banned along with many other works that had been published in South Vietnam. Nonetheless, he continued to publish in the United States until his death in 1997, and Vietnamese in the diaspora continued to be familiar with his account of early history. It is thus perhaps not surprising that it is from the diaspora that an updated, and more "scientific," version of Kim Định's interpretation of early history emerged at the turn of the 21 st century. The person who proposed this more scientific version of Kim Định's model was a Vietnamese immigrant to Australia by the name of Cung Đình Thanh.

\section{THOUGHT}

Cung Đình Thanh was born in Thái Bình Province in northern Vietnam in 1937. He must have migrated to South Vietnam in 1954 following the Geneva Accords, as his name appears in a list of students who obtained their baccalaureate in 1956 in Saigon (Công báo Việt Nam Cộng Hòa 1957). ${ }^{2}$ He subsequently obtained licentiates in law and letters as well as a degree in administration and leadership from the University of Connecticut. Upon returning to South Vietnam, Cung Đình Thanh became a lawyer for the Court of Appeals and also taught at the National Institute for Administration. He then turned to educational and cultural pursuits, serving as a superintendent of some schools, editing a journal called Cultural Development (Phát triến văn hóa), and participating in various cultural organisations. When the Vietnam War ended in 1975, Cung Đình Thanh ceased to engage in all of these activities. In 1989 he migrated to Australia, and from his new home in New South Wales, he gradually became active again. He established an organisation called Vietnam International Culture Development Inc. that was dedicated to promoting the development of Vietnamese culture. The main avenue for doing this was through the print and online publication of a journal called Thought (Tu turóng) that Cung Đình Thanh published from 1999 until his death in 2006 (Who's who in Vietnam 1974; "Cung Đình Thanh" n.d.).

The first issue of Thought contained an "open letter" from Cung Đình Thanh called "A Bird's Call to the Flock." Cung Đình Thanh began this essay by noting that he was pleased to see the idea expressed in various forms of media at that time that culture could play an important role in overthrowing authoritarianism and in liberating ideas so that people could contribute their utmost to developing the homeland. It is unclear what exact reports Cung Đình Thanh was referring to, but as Internet use became more widespread in the 1990s, there was undoubtedly more communication, at least among 
Vietnamese overseas, and with the end of the Cold War and the opening of Vietnam to the outside world, one of the topics that clearly was discussed was the possibility that Communist rule in Vietnam might come to an end. Cung Đình Thanh stated in this essay that such a day was not far off, but that this posed a major problem as Vietnamese society lacked an obvious substitute for Marxist ideology. Cung Đình Thanh's "bird's call to the flock" was thus a call for like-minded souls to develop ideas that could serve as a foundation for a new Vietnamese society, one that could thrive in the global world. To do this, Cung Đình Thanh proposed that a history of Vietnamese thought be written, and he presented an outline of such a book in this essay. He recognised, however, that it would take time to produce such a work, and he called on his readers to assist by sharing their ideas and scholarship (Cung 1999a). ${ }^{3}$

\section{RICE}

The flock clearly heard the call, as the second issue of Thought contained a contribution from a reader in the form of a Vietnamese translation of an article that American anthropologist Wilhelm "Bill" Solheim had published in National Geographic in 1971 (Solheim 1999). Entitled "New Light on a Forgotten Past," the main point of this article was summarised succinctly in a caption to one of the accompanying photographs where it stated that, "The author, acclaimed as 'Mr. Southeast Asia' by fellow prehistorians, puts forth in these pages his revolutionary theory that Southeast Asians may have been the first to make pottery, grind and polish stone tools, plant rice, and cast bronze" (Solheim 1971: 331). This, however, did not turn out to be the case. Subsequent archaeological work demonstrated that this "revolutionary theory" that Solheim proposed was not accurate, and by the late 1970s Western archaeologists and prehistorians all realised this.

However, the mere fact that an "international" scholar made "scientific" statements that indicated that agriculture "might" have first emerged in Southeast Asia was important to Cung Đình Thanh. Also important to Cung Đình Thanh was, as we will see in the following discussion, the fact that Solheim used a term that was connected to Vietnam to label what he proposed was evidence of early Neothlithic societies in Southeast Asia, "Hoabinhian." Essentially what Cung Đình Thanh did was to connect together various statements that Solheim made in order to claim that people in Vietnam were the first to cultivate rice. To understand how he did this, we need to first gain an understanding of what exactly some archaeologists discovered in the 1960s and what exactly Solheim stated about their findings. 
Solheim's claim in National Geographic that Southeast Asia might be where plants were first domesticated had earlier been proposed in 1952 by American geographer Carl O. Sauer in his Agricultural Origins and Dispersals. Sauer made this proposal based on speculation rather than archaeological evidence. He stated, for instance, that:

As the cradle of earliest Agriculture, I have proposed Southeastern Asia. It meets the requirements of high physical and organic diversity, of mild climate with reversed monsoons giving abundant rainy and dry periods, of many waters inviting to fishing, of location at the hub of the Old World for communication by water or by land. No other area is equally well situated or equally well furnished for the rise of a fishing-farming culture (Sauer 1952: 24-25).

In other words, Sauer first came up with a conceptual model for the environmental setting where he believed agriculture should have initially emerged, and then he looked for a place on the planet which fit that model and found Southeast Asia. He did not actually find archaeological evidence to support his ideas.

However, in the 1960s two of Solheim's students, Chester Gorman and Donn Bayard, initially suspected that they might have found such archaeological evidence in Thailand when they investigated two archaeological sites: Non Nok Tha in north-eastern Thailand and Sprit Cave in north-western Thailand. At Non Nok Tha, Bayard reported that rice chaff had been found that he believed must date to at least 3,500 BCE (Bayord 1970: 135). Meanwhile, at Spirit Cave Gorman found the remains of leguminous plants that he stated may have been domesticated rather than gathered, and which dated to approximately 7,000 BCE (Gorman 1969: 672).

In the report on his excavation, Gorman referred to the Spirit Cave site as "Hoabinhian." This term, "Hoabinhian," comes from "Hòa Bình," the name of a province in northern Vietnam where in the 1920s French archaeologist Madeleine Colani discovered evidence of early human habitation. The most important feature of this archaeological site were the remains of flaked stone tools (Colani 1927). Subsequently, in 1932, a meeting of prehistorians was held in Hanoi where the term "Hoabinhian" was adopted to refer to such early human settlements that were distinguished by the use of flaked stone implements (Matthews 1966: 86). Another defining feature of the Hòa Bình site was that there was no evidence of agriculture, and therefore, the term "Hoabinhian" was subsequently used to refer to Mesolithic sites, the Mesolithic period being an intermediary stage between the Paleolithic and the Neolithic 
and extending from roughly 15,000 to $5,000 \mathrm{BCE}$, a time when people still engaged in hunting and gathering rather than agriculture.

The leguminous plant remains that Gorman found at Spirit Cave, an otherwise classic Hoabinhian site, along with the rice specimens that Bayard found at Non Nok Tha, led Solheim to put forth some bold hypotheses. In his article in National Geographic in 1971 Solheim stated that he agreed "with Sauer that the first domestication of plants in the world was done by people of the Hoabinhian culture (a term Sauer had not used), somewhere in Southeast Asia," and that he would not be surprised to find that "this had begun as early as 15,000 BC" (Solheim 1971: 339). Solheim stated further that rather than it being the case that technological achievements had moved southward into Southeast Asia in the past, as was widely believed, the opposite may have been the case. To quote:

The traditional reconstruction of Southeast Asian prehistory has had migrations from the north bringing important developments in technology to Southeast Asia. I suggest instead that the first Neolithic (that is, late Stone Age) culture of North China, known as Yangshao, developed out of a Hoabinhian subculture that moved north from northern Southeast Asia about the sixth or seventh millennium BC (Solheim 1971: 339).

Finally, a year later, in 1972, Solheim published an article in Scientific American entitled "An Earlier Agricultural Revolution," in which he declared that "The agricultural revolution, which was thought to have first occurred some 10,000 years ago among the emerging Neolithic societies of the Middle East, seems to have been achieved independently thousands of miles away in Southeast Asia" (Solheim 1972: 34).

\section{HÒA BÌNH}

While these were exciting claims, again, they ultimately proved to be false. As archaeologist Miriam Stark noted (2014) in an essay of remembrance for Solheim, "Subsequent field-based investigations - and analyses by his students and close associates - did not support Bill's claims that Southeast Asia had the earliest farming or plants." Indeed, by the late 1970s various scholars had determined that the rice specimens found by Gorman and Bayard were strains of wild, rather than cultivated, rice (Yen 1980; 1982). Today the scholarly consensus among prehistorians is the opposite of what Solheim proposed, as 
experts argue that technologies like rice cultivation and metallurgy all moved southward into Southeast Asia (Castillo 2011; Higham et al. 2015).

While Solheim made some bold predictions that did not come to fruition, his declarations from the early 1970s clearly impressed Cung Đình Thanh as he published an article in 1999 in the fourth issue of Thought where he used information about Gorman's initial findings and Solheim's subsequent statements to argue for the existence of rice cultivation at a site in Hòa Bình province called Xóm Trại Cave (Hang Xóm Trại). Without citing where he got his information, Cung Đình Thanh claims in this article that there were grains of rice found at Xóm Trại Cave that resembled the rice specimens that Gorman had found at Spirit Cave and which Gorman had initially proposed showed evidence of being domesticated (a proposal which, as we have seen, had been discredited by the late 1970s). Cung Đình Thanh states that these rice samples from Xóm Trại Cave dated from around 3,500 BCE. He then implied that there was a much longer tradition of rice cultivation at Hoabinhian sites by quoting Solheim's National Geographic article where Solheim had stated that, "I agree with [Carl O.] Sauer that the first domestication of plants in the world was done by people of the Hoabinhian culture (again, a term that Sauer did not use), somewhere in Southeast Asia. It would not surprise me if this had begun as early as 15,000 BC" (Cung 1999b; Solheim 1971: 339).

If rice had been cultivated in Southeast Asia in 15,000 BCE, that would have been much earlier than the evidence for rice cultivation in China, and Cung Đình Thanh attempts to demonstrate that this is a technique that did indeed spread from the Hoabinhian world northward. In making this point, Cung Đình Thanh cites studies about the cultivation of rice in China that were published in the 1970s and early 1980s, such as a 1983 book chapter on the origins of the cultivation of grains and legumes in China by Zhang Deci (Chang Te-Tzu). An agricultural and environmental scientist at the International Rice Research Institute in the Philippines, Zhang was working under the assumption that the genus (Orzya) from which current species of rice evolved originated in the area of what is now South Asia, a theory that has been challenged by genetic scientists who now argue that Orzya evolved in multiple locations from a common wild ancestor (Kovach et al. 2007). In his 1983 book chapter, as well as in an earlier article in 1976, Zhang discusses different routes by which he argued two wild rice sub-species of Orzya, Orzya sativa Japonica and Orzya sativa Indica, spread to China. In the case of Orzya sativa Indica, Zhang states that wild relatives of this sub-species "... could have been brought from Indochina and dispersed along the seacoast up to [Hubei]" (Chang 1983: 72). He then states that, "The true domestication process probably first took 
place in China" (Chang 1983: 73, see also Chang 1976a: 143-145). This is an idea that Zhang had expressed earlier, stating in an article in 1976 that, "Cultural techniques such as puddling and transplanting were first developed in north and central China and later transmitted to Southeast Asia" (Chang 1976b: 425). It is also an idea that was widely accepted by the 1990s and was presented even in popular journals like Science (Normile 1997: 309).

Hence, Zhang Deci argued that strains of wild rice spread into China, not that wet rice cultivation began outside of, and then spread into, China. However, this latter point is precisely what Cung Đình Thanh claimed based on his (mis)reading of Zhang's chapter. Cung Đình Thanh does this by first discussing Zhang's work, but he omits the critical point that Zhang wrote about the spread of wild rice rather than cultivated wet rice (lúa nước). In doing so, Cung Đình Thanh transforms Zhang's argument that wild rice spread northward from Indochina toward the Yangzi River basin into an argument that the practice of wet rice cultivation spread over that same area. In the process, Cung Đình Thanh also miscites Zhang's work and injects novel historical information. To quote, Cung Đình Thanh states that Zhang Deci "affirms that this rice (Orzya sativa Indica) was brought (to China) from Indonesia (sic, Zhang said 'Indochina') and that it was developed along the coast from Hebei (sic, Zhang mentioned 'Hubei') to the area to the south of the Yangzi River around Shanghai, traversing the important route of Zhejiang Province, the place which later, during the Warring States period, was where the Kingdom of Yue (Việt) under the Yue king Goujian was located." Cung Đình Thanh goes on to state that, "As demonstrated above, one of the earliest centres of wet rice [cultivation] known to humankind is Hòa Bình, now in Vietnam. The cultivation of wet rice therefore was present in this region 10,000 years ago" (Cung 1999b).

This conclusion that Cung Đình Thanh reaches is not based on evidence. By the time he wrote his article in 1999, the speculations of Gorman and Solheim about early plant domestication in Southeast Asia had long been discredited, and Cung Đình Thanh had simply misunderstood the fact that Zhang Deci had talked about the northward spread of wild rice in the past rather than domesticated wet rice. Instead, what Cung Đình Thanh does in this article is to put together an argument that is based on the connections between certain names and statements that appeared in the writings that he cited, rather than actual scholarly evidence.

More specifically, what was important to Cung Đình Thanh was that Gorman found rice grains at Spirit Cave, that Solheim stated that plants in the region could have been domesticated as early as 15,000 BCE, that both 
Gorman and Solheim used the term "Hoabinhian," and that Zhang Deci stated that one way in which rice spread to China was northward along the coast from Indochina. What was not important for Cung Đình Thanh was that the rice grains Gorman found turned out to be wild rather than domesticated, that Solheim's hypothesis never proved to be true, that Gorman and Solheim used the term "Hoabinhian" to refer to sites in Thailand not in Hòa Bình Province in Vietnam, and that Zhang Deci had referred to the northward spread of wild rice not cultivated wet rice. In other words, by focusing on certain words and statements, Cung Đình Thanh created an argument that rice had been cultivated in Hòa Bình as early as 10,000 years ago and had then spread northward to the Yangzi River Delta.

Of key importance here is the way that Cung Đình Thanh transformed the term "Hoabinhian," a term that is used by international scholars in a generic sense, into the more specific, and Vietnamese-centric, referent, Hòa Bình. As mentioned above, Hoabinhian is an internationally accepted term to refer to the material remains of Mesolithic hunter-gatherers who used flaked stone implements and who inhabited a geographic region extending from Yunnan Province in what is today China to the Indonesian island of Sumatra. Further, the fact that certain material remains are labelled "Hoabinhian" is merely because the first specimens of the flaked stone tools that exemplify this archaeological culture were found in Hòa Bình Province in Vietnam. To date, international archaeologists have never identified a "centre" or a "birthplace" of Hoabinhian culture. Cung Đình Thanh, however, clearly saw Hòa Bình Province in Vietnam as the centre of everything Hoabinhian that international scholars mentioned regardless of where in Southeast Asia they were referring to. By doing so, Cung Đình Thanh not only became convinced that wet rice was present in Hòa Bình 10,000 years ago, but that this meant that Hòa Bình might be "one of the three cradles of cultivation in the world" (môt trong ba cái nôi phát sinh ra việc trồng trọt trên thế giới), alongside South America and the Middle East, with South America providing the world with cassava, the Middle East, wheat, and Hòa Bình, wet rice (Cung 1999b). This view of Hòa Bình as a civilisational centre is one that the scholars discussed below have likewise maintained.

Hence Cung Đình Thanh saw Hòa Bình as not only the centre of the ancient Hoabinhian world, but as the birthplace of wet rice cultivation. Having established this "fact" through his creative reading of the works of international scholars, Cung Đình Thanh then sought to explain what historical factors would have enabled knowledge about wet rice cultivation to spread from Hòa Bình to places as far away as the Yangzi River Delta. He does this 
in another article in the third issue of Thought in which he seeks to connect the domestication of plants in Hòa Bình and a northward migration of people away from that area to an instance of rising sea levels in the past. In particular, he argues that there is a general tendency among human beings to move towards lowlands and towards the sea. Therefore, as early as 30,000 years ago, he argues, the "ancient Việt" (Việt cổ) were already living in the Red River Delta region. Then, however, sea levels started to rise between 20,000 to 17,000 years ago at the end of the last ice age. This, Cung Đinh Thanh argues, pushed the ancient Việt back to the foothills and mountains, where they were forced to start engaging in the cultivation of plants. He states that this led to the emergence of Hòa Bình culture. Cung Đình Thanh also argues that the rising sea levels forced people by $8,000 \mathrm{BC}$ to migrate even further away, and this is what led to the spread of wet rice cultivation to places in Thailand and the Yangzi River Delta (Cung 1999c).

\section{INTERNATIONAL SCHOLARSHIP}

Cung Đình Thanh’s reliance on scholarship by non-Vietnamese scholars points to an important aspect of not only his writings but those of other Vietnamese scholars on this same topic as well - the reliance on the idea of the superiority of "international scholarship." This is a point that comes through clearly in an article that was published online in 2001 on this same topic of agriculture in Hòa Bình by Dr. Nguyễn Thị Thanh, a medical doctor in Canada. Born in Quảng Trị Province, in central Vietnam, Nguyễn Thị Thanh obtained a medical degree in Paris in 1965. She taught for a time at the University of Moncton in New Brunswick, Canada, but then returned to South Vietnam where she ultimately established her own clinic. She remained there after the Vietnam War ended. A brief biographical note on the Internet states that she was subsequently imprisoned for three years for opposing the "corrupt regime" (chế độ tham nhũng). Finally, in 1988 Nguyễn Thị Thanh migrated to Canada where she patented a method that she developed for treating cancer and viral infections using fungicides (Vo 2002).

In 2001 Nguyễn Thị Thanh published an article called "Việt Nam, the Oldest Centre of Wet Rice Agriculture and Stone Industry in the World" on a website hosted by an organisation called the Vietnamese Catholic News Agency (Thông Tấn Xã Công Giáo Việt Nam), which at the time was located in Huntington Beach, California. In her discussion of the past, Nguyễn Thị Thanh follows the model that Lương Kim Định set decades earlier of 
imagining that the ancestors of the Vietnamese originally inhabited the area of what is today China and that the pastoralist Han Chinese then migrated in, drove the ancestors of the Vietnamese southwards, and appropriated their knowledge of agriculture. In arguing that the ancestors of the Vietnamese did know how to cultivate plants, Nguyễn Thị Thanh, like Cung Đình Thanh, turns to the writings of Wilhelm Solheim, and cites a long quote from a 1967 article in Science where Solheim had also stated what scholars "might" come to conclude one day in the future. To quote, Solheim wrote that:

I think it quite possible that as we recover more data from Mainland Southeast Asia we will find that the first domestication of plants in the world was achieved by the Hoabinhian peoples sometime around $10,000 \mathrm{BC} \ldots$ that northern and central Mainland Southeast Asia had progressive cultures within which the first stone grinding and polishing in Asia, if not the world, developed and pottery was invented; that not only did this first domestication of plants, as suggested by Sauer, provide the idea of agriculture to the West (and later a number of plants to India and Africa) but that Mainland Southeast Asia continued as the progressive area in the Far East until China took over this momentum during the first half of the second millennium BC (Solheim 1967: 889).

In addition to Sauer's study, Solheim mentions the work of other scholars in this article in Science that he claims point to Southeast Asia's importance as a potential source of world agriculture as well. However, in doing so Solheim highlights points that fit with his argument and omits to mention information that does not. For instance, he states that Soviet botanist Nikolai Ivanovich Vavilov "appears to be the primary source presenting the primacy of Southeast Asia in the origin of many cultivated plants" (Solheim 1967: 898). While it is true that Vavilov argued that some plants had been domesticated in Southeast Asia, and lists some examples from island Southeast Asia rather than from the mainland, he argued that China was "the earliest and largest independent centre of the world's agriculture and the origin of cultivated plants" (Vavilov 1951: 21, 28-30). He also noted that China was followed by India in terms of the number of domesticated species that were introduced there, but that India is particularly significant because "India is undoubtedly the birthplace of rice" (Vavilov 1951: 29).

Solheim also mentions in this article the work of Kwang-chih Chang (Zhang Guangzhi), an archaeologist who argued that evidence of the burning of forests on Taiwan around 11,000 years ago was perhaps for the purpose of slash-and-burn agriculture, and that people at that time might have cultivated 
roots and fruits. Chang also identified a type of pottery from that time period that he referred to as "Corded Ware," as it was marked with chords (Chang 1972: 63). Solheim relates this pottery to a type of chord-marked pottery found in some Hoabinhian sites and states that, "Associated with this pottery and the stone tools - the typical Hoabinhian monofacially flaked tool would serve as a fine hand hoe - are quantities of fresh shells or seashells. . and animal bones." He then makes the conclusion that, "Thus we have a huntinggathering culture with good tools for working in the soil, a promising situation for domestication of root plants" (Solheim 1967: 898).

While the situation at Hoabinhian sites may indeed have been promising for the domestication of root plants, neither Solheim nor any of these other scholars actually provided evidence of Hoabinhian agriculture. Nonetheless, Nguyễn Thị Thanh states that Sauer, Solheim, Chang and Vavilov all recognise that "Southeast Asia, with Vietnam at the lead, had a prehistoric culture that developed very early, and that was advanced, swift, creative and vibrant such as no other that had ever been witnessed anywhere else in the world" (Nguyễn 2001). She then states more specifically regarding Hòa Bình that:

Based on archaeology, every secret of prehistory has been revealed. And the world has recognized Vietnam, symbolized by Hòa Bình culture, a name that has been internationalized (Encyclopédie d'Archéologie) and has been confirmed by the world, to be the place with the earliest wet rice agriculture and stone tool industry in the world (Nguyễn 2001).

In other words, to Nguyễn Thị Thanh international scholars are the ultimate arbiters of the truth, and she essentially seeks to shame Vietnamese into not realising what it is that international scholars have long recognised. The problem here, of course, is that by the time Nguyễn Thị Thanh wrote her article, international scholars had long determined that the guesses of Solheim and others in the 1950s and 1960s were not true. There is thus a contradiction in simultaneously pointing to the expertise of international scholars and ignoring the (updated) expertise of international scholars. However, that contradiction is clearly acceptable for Nguyễn Thị Thanh and others because of their desire to depict a glorious past for the Vietnamese. 


\section{GENETICS}

In the April 2000 issue of Thought, Cung Đình Thanh and a colleague, Dr. Nguyễn Đức Hiệp, introduced readers to an exciting new topic - the insights that genetic science was offering the study of human evolution and migration. At the time, Nguyễn Đức Hiệp was working as an atmospheric scientist in New South Wales, Australia. Born in Vietnam, Nguyễn Đức Hiệp went to Australia in 1974 to study and received a $\mathrm{PhD}$ in engineering from the University of Western Australia in 1978 and another $\mathrm{PhD}$ in electrical engineering from the University of Sydney in 1985 (Nguyễn 2016; "Nguyễn Đức Hiệp" n.d.). In the April 2000 issue of Thought, Nguyễn Đức Hiệp noted that there are certain discoveries that can dramatically change our understanding of the past, such as when in the 19th century Orientalist James Princep deciphered edicts originally written in the third century BCE by emperor Ashoka, thereby bringing to light a previously unknown chapter of Indian history. This, Nguyễn Đức Hiệp argued, is precisely what genetic science was now doing for the early history of human migration (Nguyễn 2000).

In his article, Nguyễn Đức Hiệp introduced readers briefly to the work of L. Luca Cavalli-Sforza, a genetic scientist at Stanford University who published a book and various articles in the 1990s that revealed what genetic science can tell us about human evolution and the peopling of the planet (Cavalli-Sforza 1997, 1998; Cavalli-Sforza et al. 1994). In the 1990s there were two main theories concerning human evolution. One argued that Homo Erectus migrated out of Africa some one million years ago and then evolved independently into Homo Sapiens in different locations. The main support for this theory came from the field of archaeology. Over the course of the 1990s, however, this theory lost its persuasiveness as scholars such as Cavalli-Sforza demonstrated that genetic science made it evident that the people outside of the African continent today are all the descendants of a small population of Homo Sapiens who migrated out of Africa sometime around 70,000 years ago. This genetic evidence supported the other main theory of human migration, which argued that Homo sapiens evolved in Africa first and then migrated to the rest of the world, where they ultimately replaced the descendants of the earlier Homo erectus migration.

While this genetic information convinced many, there were scholars in China who continued to argue that modern humans had evolved independently in China. In response to that claim, a group of genetic scientists led by J. Y. Chu tested this hypothesis by examining DNA evidence from certain, mainly minority, populations within China. Chu and his colleagues were particularly 
interesting in seeing if there was a distinction between the peoples of northern and southern China, and if so, if this information could illuminate ancient migration patterns. The results of their research were published in 1998 (Chu et al.) and Nguyễn Đức Hiệp devoted the majority of his article to discussing this study.

$\mathrm{Chu}$ and his colleagues concluded that "populations in East Asia were subjected to genetic contributions from multiple sources: Southeast Asia, Altaic from northeast Asia, and mid-Asia or Europe." However, they were unable to determine "the relative contributions from each source" as the data set came largely from minority populations and was therefore not fully representative of the population of China as a whole. Nonetheless, they did recognise a distinction between the populations of northern and southern China, and argued that "the southern populations in East Asia may be derived from the populations in Southeast Asia that originally migrated from Africa, possibly via mid-Asia, and the northern populations were under strong genetic influences from Altaic populations from the north." While Chu and his colleagues were unable to determine whether Altaic populations had migrated into or originated in the region, in examining their genetic evidence together with information from various studies of cranial and dental traits of populations in the region, they concluded that "it is more likely that ancestors of Altaic-speaking populations originated from an East Asian population that was originally derived from Southeast Asia, although the current Altaicspeaking populations undeniably admixed with later arrivers from mid-Asia and Europe" (Chu et al. 1998: 11767).

\section{A NEW SCIENTIFIC HISTORY}

In presenting this information, Nguyễn Đức Hiệp made the comment that given the fact that Hòa Bình is one of the oldest archaeological sites in Southeast Asia, that "Therefore there is real evidence and a foundation [to support the idea that] Hòa Bình people migrated to the north and are the ancestors of the people of East Asia" (2000). After making this point, Nguyễn Đức Hiệp cited some of the articles that Cung Đình Thanh had published in earlier issues of Thought that argued this point. Meanwhile, in this same issue of Thought, Cung Đình Thanh incorporated this new genetic information into his own outline of early history in an article entitled "Based on Advances in Genetics (DNA), Perhaps the Time has Come that We can Affirm the Origins of the Vietnamese People?" (Cung 2000). 
In this article, Cung Đình Thanh points out that previous studies about the origins of the Vietnamese had relied on either texts or skeletal remains. During the colonial era, there were French scholars who interpreted ancient Chinese texts to argue that the Vietnamese had historically migrated southward into the Red River Delta from areas in China, and there were Vietnamese scholars who had followed this interpretation as well. During the colonial era, there were also early French archaeologists who had sought to determine the race of the first inhabitants in the region based on examinations of skulls that had been unearthed in archaeological sites. This is a practice that Vietnamese scholars continued to engage in well into the 1980s, and while different scholars put forth different theories, they all revolved around the idea that the Vietnamese were the product of some degree of interracial mixing that had taken place in the region in antiquity, such as between "Indonesiens" from the island world and "Mongoloids" from the north.

Cung Đình Thanh admits that he had long tried to understand the past through these approaches but that genetic science now demonstrates that both of those perspectives are incorrect, as they both assume that there was some northern population that influenced the Vietnamese, whereas the genetic evidence points to the opposite, that people from Southeast Asia migrated northward. Further, Cung Đình Thanh states that the people who migrated northward were members of the Hòa Bình culture (văn hóa Hóa Bình) and that they may have migrated northward primarily from the very area of Hòa Bình in northern Vietnam, and that they definitely contributed to the creation of the country of China (Cung 2000).

At the time that Cung Đình Thanh wrote this article, genetic scientists had not yet determined when exactly a northward migration of peoples into East Asia had taken place. In an article from late 1999, a group of genetic scientists, including J. Y. Chu, argued simply that "the first entry of modern humans into the southern part of eastern Asia was $\sim 60,000$ years ago, followed by a northward migration coinciding with glaciers receding in that area" (Bing et al. 1999: 1723). However, subsequent studies did take up the issue of dating that northern migration. In 2005, for instance, a group of genetic scholars placed the northern migration of early humans into East Asia at around $~ 25,000$ 30,000 years ago, that is, well before the Hoabinhian period, and long before the domestication of plants (Hong et al. 2008). Meanwhile, in 2008 another study identified an even earlier northward migration of early humans into East Asia starting around 60,000 years ago (Hong et al. 2008). This finding appears to fit with the results of a study from 2011 that concluded that Southeast Asia was populated by two main dispersals, the second of which led to the peopling of East Asia (Reich et al. 2011). 
The picture that is now emerging is of early humans arriving in Southeast Asia in two dispersals, and of two northward migrations into East Asia. These events occurred well before there is evidence of a Hoabinhian culture, and long before there is any evidence of plant domestication or agriculture in Southeast Asia. Finally, these two very early northward migrations were ultimately followed by a much later southward movement of peoples whom we would today call "Han Chinese" over the past two or so millennia from areas of what is now northern China to areas to the south of the Yangzi River (Wen et al. 2004).

There are thus two very fundamental flaws in Cung Đình Thanh's argument. The first is that while Solheim hypothesised that "the first domestication of plants in the world was done by people of the Hoabinhian culture, somewhere in Southeast Asia," this did not prove to be true, and that was already clear at the time that Cung Đình Thanh wrote. The second flaw is that the genetic evidence for the peopling of East Asia demonstrates that people migrated into East Asia long before there is evidence of Hoabinhian culture and long before there is evidence of the domestication of plants and agriculture in Southeast Asia, and that therefore, these migrants could not have come from the world of Hoabinhian culture, as Cung Đình Thanh imagined it. This second point may not have been clear at the time that Cung Đình Thanh wrote, but it is now, and as we will see below, Cung Đình Thanh's ideas are nonetheless currently being promoted by an author in Vietnam. That said, Cung Đình Thanh clearly envisioned that he was in the process of creating a new and more scientific history of the Vietnamese, and he declared that "We feel that the time has come when we must reappraise past theories about the origins of the Vietnamese people in order to bring them into accord with the scientific advances of the present" (Cung 2000).

\section{EDEN IN THE EAST}

Shortly before Cung Đình Thanh started to publish his writings on early history, Stephen Oppenheimer, a British paediatrician with years of experience working in Southeast Asia, published a book entitled Eden in the East: The Drowned Continent of Southeast Asia (1998), that made claims that overlapped with what Cung Đình Thanh would write. In this work, Oppenheimer argues that Southeast Asia, rather than the Middle East or China, is the earliest "cradle of civilisation." It is there, he argues, that the Neolithic Revolution first took place, and it is from there that knowledge about agriculture spread to other 
parts of the world. Finally, Oppenheimer argues that the evidence for this Southeast Asian cradle of civilisation has largely disappeared as the territory where this civilisation supposedly emerged, the Sunda continental shelf, was submerged at the end of the last ice age. Nonetheless, Oppenheimer points to various traces of evidence from multiple disciplines ranging from archaeology and linguistics to geology and myths that he argues support his case.

In writing about Southeast Asia, Oppenheimer focuses mainly on the island world, and says very little about Vietnam. The dominant theory about the early history of island Southeast Asia is that a population of Austronesian language speakers began to migrate into the region from Taiwan starting around 5,000 years ago. This "out of Taiwan" thesis argues that as these peoples migrated into the region they introduced, among other practices, rice farming and the production of certain types of pottery (Bellwood 2004). Although this is the main theory for the early history of the region, Solheim (1996) offered an alternative explanation for the spread of Austronesian speakers, arguing that they emerged in the region and spread outward from the area of what is now Eastern Indonesian at the time of the end of the last ice age through longestablished trading networks.

Oppenheimer builds on Solheim's theory by arguing that agriculture first emerged in Southeast Asia and then as people were forced to migrate due to rising sea levels at the end of the last ice age, they spread not only themselves and their languages, but knowledge about agriculture from this "cradle of civilisation." However, the evidence that Oppenheimer builds this argument on is extremely thin and problematic. For the existence of the cultivation of rice in Southeast Asia, for instance, Oppenheimer cites (1998: 68-69) a report of an archaeological excavation of a cave site in southern Thailand which mentions that "rice grains" were found at a level that is dated to somewhere roughly between 7,000-9,000 years ago. That report did not indicate whether those grains were from domesticated or wild rice, but Oppenheimer notes that "if" those dates are correct for domesticated rice, then it would be clear that rice was domesticated independently in Southeast Asia (Oppenheimer 1998: $83)$.

Building an argument on a supposition is dangerous, and in this case it has proven to be fatal, as the earliest evidence of domesticated rice in Thailand currently dates from 2,000-1,500 BCE, and it is the variety of rice that scholars argue was first domesticated in the area of the Yangzi River valley (Castillo 2011: 115-116). Nonetheless, the mere mention of the possibility that rice might have first been domesticated in Southeast Asia was enough to excite some overseas Vietnamese readers of Oppenheimer's book. Eden in the East 
appears to have first been introduced to Vietnamese-language readers in 2000 in a magazine in California called 21st Century (Ngô Thế Vinh), however I have been unable to locate this review. Then in August 2001 a review was published in Thought, and republished in December in 21st Century. This review was authored by an epidemiologist by the name of Nguyễn Văn Tuấn. Born in Kiên Giang Province in the far southwest of Vietnam, Nguyễn Văn Tuấn fled the country in 1981 as a "boat person" and ended up in Australia, where he obtained a medical degree. At the time that he wrote a review of Oppenheimer's Eden in the East, Nguyễn Văn Tuấn was an associate professor of epidemiology at Wright State University in the United States ("Nguyễn Văn Tuấn" n.d.).

In reviewing Eden in the East, Nguyễn Văn Tuấn highlights what he sees as the book's three main points. These are to show that during the last ice age a large area in Southeast Asia that is now submerged was above sea level, that around 9,000-10,000 years ago people in this area started to engaged in agriculture, and that as sea levels started to rise with the end of the last ice age around 8,000 years ago people from this area dispersed in all directions (Nguyễn 2001:12). These last two points are of particular importance to Nguyễn Văn Tuấn as he relates them to the early history of the Vietnamese. Again, although Oppenheimer does not focus on the early history of Vietnam, Nguyễn Văn Tuấn argues that the findings in Eden in the East can provide support to a new perspective on the Vietnamese past. To quote, he states that thanks to Oppenheimer's book:

We have evidence to declare that before engaging in contact with the Han coming from the north (China), our ancestors had created a rather sophisticated civilization, if we do not want to say the most sophisticated in Southeast Asia... Our ancestors developed and made use of the technology of rice cultivation before the Han, or were the people who taught the Han to cultivate rice (not the opposite). And it is possible that our ancestors are the very ancestors of the Chinese of today. The time has come to return the truth and glory to our ancestors (Nguyễn 2001:14).

Oppenheimer's book does not support the claims that Nguyễn Văn Tuấn made here, and there were Vietnamese readers of his review that easily recognised that. One person to do so was a man in Rouen, France by the name of Nguyễn Quang Trọng (2002). In a detailed response to Nguyễn Văn Tuấn's review that was published in an online journal based in California, Nguyễn Quang Trọng challenged Nguyễn Văn Tuấn's argument point by point. With regards to the 
issue of the development of agriculture in Southeast Asia, Nguyễn Quang Trong noted that even Oppenheimer himself did not actually affirm that this was the case, as he knew that the evidence from Thailand that he cited had not been confirmed. Further, Nguyễn Quang Trọng also noted that no direct evidence of agriculture had ever been found in Hoabinhian sites in Vietnam. Nguyễn Văn Tuấn's claim that "our ancestors" had developed agriculture and had taught that technology to the Han was therefore not a fact but an example, Nguyễn Quang Trọng argued, of an exaggerated sense of self-veneration.

Another important point that Nguyễn Quang Trọng made is that it is erroneous to think of people in this early time period as being part of clearlydefined and unchanging groups. Instead, he argues that even in this early period there was a great deal of intermixing of peoples. This is precisely what more recent genetic and archaeological studies have revealed. While the out of Taiwan thesis has not been overturned, it has gained a great deal more complexity. What scholars can now see is that it was not the case that Austronesian speakers brought an entire ready-made "package" of Neolithic practices into Southeast Asia and the Pacific. Instead, some technologies associated with the Austronesian speakers likely emerged in "interaction spheres" in the area of what is now eastern Indonesia and New Guinea (Anderson and O'Connor 2008: 3). Further, not all Austronesian migrations or contacts involved agriculture. For instance, pottery, an artefact that has been used to trace Austronesian migrations, was not necessarily always associated with agriculture (Spriggs 2011: 523). Finally, genetic science is demonstrating that rather than imagining a wave of migrants overtaking a region, Austronesian speakers intermixed with well-established and numerically dominant extant populations in the region (Soares et al. 2008). In other words, scholars still agree that there were migrations into the region from the north that brought agricultural knowledge, however those migrations were part of extremely complex and diverse processes of human migrations and interactions.

As such, Eden in the East puts forth some problematic claims, and the ideas that the book inspired Nguyễn Văn Tuấn to declare are simply false. Nonetheless, Nguyễn Văn Tuấn was not alone in seeing this book as a strong support for a certain vision of the past that he wished to promote. In 2005, a Vietnamese translation of Oppenheimer's book was published in Vietnam. This Vietnamese translation included an introduction by Nguyễn Văn Tuấn that was much more subdued than his earlier pronouncement. Perhaps Nguyễn Văn Tuấn had come to realise that he had exaggerated the book's importance, but if he did, that did not matter as this translation came at the same time that Vietnamese in Vietnam were starting to write about these issues. What had 
started as a discussion among overseas Vietnamese now came to the attention of readers in Vietnam, both online and through print media.

\section{HÀ VĂN THÙY}

While there are numerous individuals in Vietnam who started to discuss this issue of early history, one writer took a leading role, a former journalist by the name of Hà Văn Thùy. Born in 1944 in Thái Bình Province in northern Vietnam, Hà Văn Thùy obtained a university degree in biology in 1967 in Hanoi. In the 1980s Hà Văn Thùy worked as a journalist based in Kiên Giang Province in the far southwest of Vietnam. In the late 1980s he became involved in a dispute with the authorities in the Association of Journalists, the organisation that all journalists must be a member of in order to work, and was ultimately expelled in 1989 ("Hà Văn Thùy" n.d.). The end of Hà Văn Thùy's formal journalistic career, however, did not lead to an end of writing, as he continued to produce writings on various topics, and in 2005 he turned to the topic of early history.

In that year Hà Văn Thùy published an article on a website called Talawas that was run by a dissident Vietnamese author based in Germany, Pham Thị Hoài. In the early 2000s, Talawas was the premiere forum for critical discussion among Vietnamese intellectuals. Many of the contributors and readers were Vietnamese living overseas, however they came from a wide spectrum of an increasingly diverse overseas population. There were those who had left at the end of the Vietnam War, others who had fled as boat people in the late 1970s and 1980s, those who had travelled to the Soviet Union and Eastern Europe during the Cold War and had remained, and there were Vietnamese nationals who were studying overseas. Finally, an increasing number of intellectuals from within Vietnam came to read and participate in Talawas as Internet use expanded in the country and as people discovered how to manoeuvre around government attempts to block access to certain websites.

Hà Văn Thùy begins his article by expressing a similar concern as Cung Đình Thanh and Lương Kim Định had, that is, a fear for the survival of Vietnamese culture. He notes that in the current age of globalisation there is a fear that Vietnamese culture will be invaded by elements from foreign cultures and that the government has therefore issued various directives about the need to preserve the essence of Vietnamese culture. However, Hà Văn Thùy argues that the more people have talked about this topic the more convoluted the ideas have become such that there was now a need to clearly establish who exactly 
the Vietnamese people are and to define what exactly Vietnamese culture is. Hà Văn Thùy acknowledges that he is not a historian, but as "a person who has a sense of responsibility for the nation's culture" he wishes to share his ideas with readers (Hà 2005).

In his article, Hà Văn Thùy repeats much of what Cung Đình Thanh, Nguyễn Đức Hiệp, Nguyễn Văn Tuấn and Nguyễn Thị Thanh had already written, and he thanks these authors and others in a note at the end of his article. At the same time, he also tries to go beyond the work of these writers and to more closely connect their ideas to those that Lương Kim Định had produced in the 1960s and early 1970s, as well as to ideas about the historical formation of races that a Vietnamese scholar by the name of Nguyễn Đình Khoa had proposed in a 1983 book entitled The Racial Anthropology of Southeast Asia.

The field of anthropology (nhân họ) only started to emerge in Vietnam in the 1990s after the country opened to academic exchanges with Western countries and Japan. Prior to the 1990s, anthropological knowledge was produced by scholars in two fields: ethnology (dân tộc học) and racial anthropology (nhân chüng hoc). The scholars in these fields focused on classifying human groups, be it in ethnic or racial terms. These efforts began with the work of French scholars during the colonial period but they also aligned with the types of scholarship that Soviet scholars engaged in as well. Nguyễn Đình Khoa built on the work of French and Soviet scholars, as well as his own anthropometric research, to argue that there were originally two races of people in the area of Vietnam: Austroloids and Mongoloids. Their intermixing produced racial subgroups such as Indonesiens and Melanesiens, racial types that French scholars had first proposed during the colonial period and had applied to skulls found in early archaeological sites. Then during the Bronze Age the Austroloid elements receded and the Mongoloid elements became dominant, and this is what we see in the Vietnamese population (Nguyễn 1983: 106).

Hà Văn Thùy takes these ideas and combines them with what Lương Kim Định and Cung Đình Thanh and his colleagues had written to create the following narrative of early history: The prehistoric inhabitants of Southeast Asia consisted of two main racial types: Mongoloids and Austroloids. One group of Mongoloids migrated northward and became "Northern Mongoloids," a large racial category from which the Han Chinese emerged. At some point after these Mongoloids migrated northward, Việt people did the same. These Việt people, according to Hà Văn Thùy, were Indonesiens, that is, a racial subgroup that was produced through the intermixture of Austroloids and Mongoloids. They were also the people who produced the Hoabinhian 
culture. They developed the Asian mainland, but then starting around 2,500 $\mathrm{BCE}$ the Han Chinese started to push the Việt southward. Intermixing took place as well, and that is why when the Việt finally returned to their "home" in Vietnam, the Mongoloid element in their racial makeup had increased, but the Indonesien element in the Han Chinese population that migrated south of the Yangzi River also increased, leading to the emergence of a "Southern Mongoloid" racial sub-category.

Through this narrative, Hà Văn Thùy seeks to explain exactly who the Vietnamese are. He spends less time discussing what exactly Vietnamese culture is, but in essence he is in agreement with Lương Kim Định that what people think of as "Chinese culture" was actually created by the ancestors of the Vietnamese. While Lương Kim Định had sought to demonstrate this through his creative use of the theory of structural anthropology and through his own concept of obscure history, Hà Văn Thùy notes that the genetic science findings of J. Y. Chu and his colleagues prove the point that Lương Kim Định sought to demonstrate: the ancestors of the Vietnamese lived in the area of China prior to the Chinese, and that therefore they are the ones who created the cultural foundation for what later became "China."

Since his foray into this field in Talawas in 2005, Hà Văn Thùy has continued to write about this topic. What is more, his writings soon began to appear in Vietnam, both in print and on web pages based in the country. In 2006 he published in Hanoi an expanded version of his Talawas article entitled Relocating the Origins of Việt Culture. This was followed by the publication of The Journey of Relocating Origins: Research and Conversations in 2008 and Finding Origins through Genetic Science in 2011. In 2014 Hà Văn Thùy published two works in America through Amazon which both address this same topic to some extent: Rewriting Chinese History (2014a), which contains an introduction by Nguyễn Đức Hiệp, and The Historical Evolution of Vietnamese Culture (2014b). Finally, in 2016 the publishing house of the Association of Writers, an official cultural organ, published Exploring Chinese History (2016a) and Contributing to the Reconceptualization of the History of Việt Culture (2016b). Meanwhile, in addition to these numerous publications, Hà Văn Thùy has written prolifically on the Internet, repeating his ideas at virtually every opportunity and challenging everyone who offers different views of the past, from the late Phan Huy Lê (2017), long the leading historian in Vietnam, to myself (2015), by engaging in one-sided "exchanges" (trao đổi) or "discussions" (thảo luận) that he posts online. 


\section{CONCLUSION}

Hà Văn Thùy is an important figure in that he synthesised elements from the various ideas that had developed concerning Vietnamese prehistory, from those that Lương Kim Định developed in South Vietnam in the 1960s and early 1970s, to those promoted by Cung Đình Thanh and others in the diaspora in the late 1990s and early 2000s, to those of scholars in Vietnam in the 1980s and 1990s. What is more, one can also see Hà Văn Thùy as a kind of "Internet bridge" in that he was one of the first individuals in Vietnam to engage with the ideas about prehistory that were developed and posted online by Vietnamese in the diaspora, and he did so first in the cyberspace outside of Vietnam before it became acceptable to discuss such ideas within Vietnam.

At the same time, however, Hà Văn Thùy is a controversial figure in that he is aggressively promoting ideas that are the purview of scholars without holding a scholarly position or affiliation. Further, whatever transpired in the past that caused him to lose his official status as a journalist continues to place him in a negative light in the eyes of some people. As such, I would argue that the combination of the ambiguity of Hà Văn Thùy's status and the ubiquity of his presence online as a spokesperson for this new version of Vietnamese prehistory, makes it difficult for many to see what is happening beyond the world of Hà Văn Thùy.

However, many of the ideas from this "fringe history" are now enjoying a position of "centrality." For instance, if one seeks to learn about "wet rice civilisation," what the Vietnamese-language version of Wikipedia ("Văn minh lúa nước" n.d.) now presents is the view of the past that makes Vietnam an early centre of the cultivation of rice that the group of writers in this essay have promoted, with references to Sauer, Solheim, Gorman and Oppenheimer, and links to the writings of Cung Đình Thanh and his colleagues. Further, if one peruses the website of the Faculty of Vietnamese Studies at Vietnam National University in Hò Chí Minh City, one will find that Nguyễn Văn Tuấn's laudatory review of Oppenheimer's Eden in the East that was published in Thought in 2001 was reposted on this university website on 3 June 2019 (Khoa Việt Nam học). In addition, the statements at the beginning of this article that Hà Văn Thùy made about Lương Kim Định in the Temple of Literature in 2012 were promptly posted to the website of the Centre of Theoretical and Applied Cultural Studies, likewise under Vietnam National University, Hò Chí Minh City. Finally, while Lương Kim Định's books were still banned at the time of that 2012 symposium, they have now been republished in Vietnam (Phạm 
2017). Hence, many of the ideas discussed in this essay, although perhaps unfamiliar to academics, are clearly important for many Vietnamese, and are here to stay.

\section{NOTES}

* Liam C. Kelley is an Associate Professor of Southeast Asian Studies at the Institute of Asian Studies at Universiti Brunei Darussalam. His background is in premodern Vietnamese history, but he is particularly interested in how the premodern Vietnamese past has been reinterpreted and re-purposed since the early 20th century. Kelley has published on the history of Sino-Vietnamese diplomatic and cultural relations, Vietnamese historiography, and Vietnamese religion. More recently, he has been publishing on the challenges that the field of Southeast Asian studies faces in the age the Digital Revolution and globalisation. For the past decade, Kelley has also maintained an academic blog: Le Minh Khai's SEAsian History Blog (https://leminhkhai.wordpress. com), where he seeks to engage with a readership beyond academia. Finally, together with Professor Phan Le Ha of the Sultan Hassanal Bolkiah Institute of Education at Universiti Brunei Darussalam, Kelley co-organises the annual conference, Engaging With Vietnam: An Interdisciplinary Dialogue.

1 The author would like to thank the two anonymous reviewers for the International Journal of Asia Pacific Studies for their extremely constructive comments.

2 I would like to thank Dr. Tuong Vu of the University of Oregon, United States for sharing this reference with me.

3 This journal is no longer available online. I have therefore relied on images of this webpage captured on 14 April 2006 by the Internet Archive's Wayback Machine. To access the articles from this journal that are cited in this essay, readers can input the cited URL into the Wayback Machine (http://archive.org/web/). Sometimes Cung Đình Thanh uploaded PDF files of the print version of Thought, and at other times he placed the articles on web pages. For the PDF files I am able to cite page numbers, but for the web pages there is no pagination.

\section{REFERENCES}

Anderson, A. and O'Connor, S.2008. Indo-Pacific migration and colonization-Introduction. Asian Perspectives 47: 2-11, https://doi.org/10.1353/asi.2008.0010.

Bayard, D. T. 1970. Excavation at Non Nok Tha, northeastern Thailand, 1968. Asian Perspectives 13 (1): 109-144.

Bellwood, P. 2004. The origins and dispersals of agricultural communities in Southeast Asia. In Southeast Asia: From prehistory to history, eds. Glover, I. and Bellwood, P., 21-40. London: RoutledgeCurzon.

Bing, S. et al. 1999. Y-chromosome evidence for a northward migration of modern humans into eastern Asia during the last ice age. The American Journal of Human Genetics 65 (6): 1718-1724, https://doi.org/10.1086/302680. 
Castillo, C. 2011. Rice in Thailand: The archaeobotanical contribution. Rice 4 (3-4): 114120, https://doi.org/10.1007/s12284-011-9070-2.

Cavalli-Sforza, L. L. 1997. Genes, people and languages. Proceedings of the National Academy of Sciences of the USA 94: 7719-7724, https://doi.org/10.1073/ pnas.94.15.7719.

1998. The Chinese human genome diversity project. Proceedings of the National Academy of Sciences of the USA 95: 11501-11503, https://doi.org/10.1073/ pnas.95.20.11501.

Cavalli-Sforza, L. L., Menozzi, P. and Piazza, A. 1994. The history and geography of human genes. Princeton: Princeton University Press.

Chang, K-c. 1972. Prehistoric archaeology of Taiwan. Asian Perspectives 13 (1): 59-77.

Chang, T-T. (Zhang Deci). 1976a. The rice cultures [and discussion]. Philosophical Transactions of the Royal Society of London: Series B, Biological Sciences 275 (936): 143-157.

1976b. The origin, evolution, cultivation, dissemination, and diversification of Asian and African Rices. Euphytica 25 (1): 425-441.

1983. The origins and early cultures of the cereal grains and food legumes. In The origins of Chinese civilization, ed. Keightley, D. N., 65-94. Berkeley: University of California Press.

Chu, J. Y. et al. 1998. Genetic relationship of populations in China. Proceedings of the National Academy of Sciences of the USA 95: 11763-11768, https://doi.org/10.1073/ pnas.95.20.11763.

Colani, M. 1927. L'Age de la pierre dans la province de Hoa-Binh (Tonkin) [The stone age in Hòa Bình province]. Mémoires du service géologique de l'Indochine [Records of the Geological Service of Indochina] 14 (1):1-126.

Công báo Việt Nam Cộng Hòa [Official gazette of the Republic of Vietnam]. 1957. 5 January.

Cung, Đ. T. 1999a. Tiếng chim gọi đàn: thu ngỏ 1 [A bird's call to the flock: Open letter 1]. Tu tuớng [Thought], 1 (March). http://tutuong.hypermart.net/htmlfiles/ThuNgo1. htm (accessed through the Wayback Machine on 1 November 2017).

1999b. Sự thuần hóa cây lúa nước và ảnh hưởng của việc biển tiến đối với tư duy của con người Việt cổ [The domestication of wet rice and the influence of the advance of the sea on the thinking of the ancient Việt people]. Tu tuoơng 3 (July): 16-21. http://tutuong.hypermart.net/pdffiles/tutuong3_extracts.PDF (accessed through the Wayback Machine on 1 November 2017).

.1999c. Khái niệm về biển tiến-Việt Nam [The concept of the sea advance-Vietnam]. Tư tương 3 (July): 11-16. http://tutuong.hypermart.net/pdf files/tutuong3_extracts. PDF (accessed through the Wayback Machine on 1 November 2017).

. 2000. Nhờ tiến bộ của di truyền học (DNA), phải chăng đã đến lúc chúng ta có thể khẳng định được nguồn gốc dân tộc Việt Nam? [Based on advances in genetics (DNA), perhaps the time has come that we can affirm the origins of the Vietnamese people?]. Tu tương 7 (April). http://tutuong.hypermart.net/html files/nguon goc dan toc vietnam.htm (accessed through the Wayback Machine on 1 November 2017).

"Cung Đình Thanh." n.d. Việt Nam văn hiến [Vietnamese civilization]. http://www. vietnamvanhien.net/CungDinhThanh.html (accessed 21 November 2017). 
Gorman, C. F. 1969. Hoabinhian: A pebble-tool complex with early plant associations in Southeast Asia. Science 163 (3868): 671-673.

Hà, V. T. 2005. Tìm lại cội nguồn tổ tiên, cội nguồn văn hoá [Relocating ancestral origins and cultural origins]. Talawas, 2 May. http://www.talawas.org/talaDB/showFile. php?res $=3789 \& \mathrm{rb}=0302$ (accessed 13 December 2017).

2006. Tìm lại cội nguồn văn hóa Việt [Relocating the origins of Việt culture]. Hanoi: Nhà xuất bản Văn học.

. 2008. Hành trình tìm lại cội nguồn: nghiên cưu và đối thoại [The journey of relocating origins: Research and conversations]. Hanoi: Nhà xuất bản Văn học. . 2011. Tìm cội nguồn qua di truyền học [Finding origins through genetic science]. Hanoi: Nhà xuất bản Văn học.

. 2014a. Viết lại lịch sủ Trung Hoa [Rewriting Chinese history]. No publication information.

.2014b. Tiến trình lịch sử văn hoá Việt [The historical evolution of Việt culture]. No publication information.

. 2015. Thảo luận với giáo sư Liam C. Kelley về triết gia Kim Định [Discussing with professor Liam Kelley about philosopher Kim Định]. Khoahocnet [Science Web], 8 July. https://khoahocnet.com/2015/07/08/ha-van-thuy-thao-luan-voi-giao-suliam-c-kelley-ve-triet-gia-kim-dinh/ (accessed 13 December 2017).

. 2016a. Khám phá lịch sủ Trung Hoa [Exploring Chinese history]. Hanoi: Nhà xuất bản Hội Nhà văn.

. 2016b. Góp phần nhận thức lại lịch sủ văn hóa Việt [Contributing to the reconceptualization of the history of Việt culture]. Hanoi: Nhà xuất bản Hội Nhà văn.

. 2017. Trao đổi với G. S. Phan Huy Lê về sủ Việt [An exchange with professor Phan Huy Lê about Việt history]. Văn hóa [Culture]. Vietnamese American Artists \& Media Association, 14 May. https://nhatbaovanhoa.com/a5705/ha-van-thuytrao-doi-voi-gs-phan-huy-le-ve-su-viet (accessed 13 December 2017).

"Hà Văn Thùy." n.d. Wikipedia. https://vi.wikipedia.org/wiki/H\%C3\%A0_V\%C4\%83n_ Th\%C3\%B9y (accessed 12 December 2017).

Higham, C. F. W., Douka, K. and Higham, T. F. G. 2015. A new chronology for the Bronze Age of northeastern Thailand and its implications for Southeast Asian prehistory. PLOS ONE 10 (9):1-20, https://doi.org/10.1371/journal.pone.0142511.

Hong, S. 2005. Y-chromosome evidence of southern origin of the East Asian-specific haplogroup O3-M122. The American Journal of Human Genetics 77 (3): 408-419, https://doi.org/10.1086/444436.

Hong, S. et al. 2008. Y chromosome evidence of earliest modern human settlement in East Asia and multiple origins of Tibetan and Japanese populations. BMC Biology 6 (45): 1-10, https://doi.org/10.1186/1741-7007-6-45.

Kovach, M. J., Sweeney, M. T. and McCouch, S. R. 2007. New insights into the history of rice domestication. Trends in Genetics 23 (11): 578-587, https://doi.org/10.1016/j. tig.2007.08.012.

Lương, K. Đ. 1970. Việt lý tố nguyên [Tracing Việt principles to the source]. Saigon: An Tiêm. . 1973. Co cấu Việt Nho [Việt Confucian structure]. Saigon: Nguồn Sáng. 
“Lương Kim Định.”n.d. Wikipedia.https://en.wikipedia.org/wiki/L\%C6\%B0\%C6\%A1ng_ Kim_\%C4\%90\%E1\%BB\%8Bnh (accessed 19 December 2017).

Matthews, J. M. 1966. A review of the 'Hoabinhian' in Indo-China. Asian Perspectives 9 (1): 86-95.

Maybon, C. B. and Russier, H. 1909. Notions d'histoire d'Annam [Ideas about the history of Annam], vol. 1. Hanoi and Haiphong: Imprimerie d'Extrême-Orient.

Ngô, S. L. 1983 [1479]. Đại Việt sử ký toàn thu [Complete book of the historical records of Đại Việt]. Hanoi: Khoa học xã hội.

Ngô, T. V. 2000. Tìm về phương Đông - Địa đàng lại đánh mất [Searching in the East A lost eden]. Thế kỷ 21 (April-May).

Nguyễn, Đ. K. 1983. Nhân chủng học Đông Nam Á [Racial anthropology of Southeast Asia]. Hanoi: Nhà xuất bản Đại học và Trung học Chuyên nghiệp.

Nguyễn, Đ. H. 2000. Khám phá mới di truyền học về nguồn gốc con người ở Đông Á (Theo báo cáo khoa học của GS. J. Y. CHU) [A new genetic discovery about the origins of people in East Asia (According to a scientific report by professor J. Y. Chu)]. Tu tương 7 (April). http://tutuong.hypermart.net/htmlfiles/Khamphaditruyenhoc_ NDH.htm (accessed through the Wayback Machine on 1 November 2017). . 2016. Sài Gòn Chơ Lớn: qua nhũng tu liệu qúy trước 1945 [Saigon and Cholon: From pre-1945 rare sources]. Ho Chi Minh: Nhà xuất bản Văn hóa, văn nghệ.

"Nguyễn Đức Hiệp." n.d. LinkedIn. https://au.linkedin.com/in/duc-hiep-8985b81b (accessed 20 November 2017).

Nguyễn, Q. T. 2002. Về nguốn gốc dân tộc Việt Nam và 'Địa đàng Phương Đông' của Oppenheimer [On the origins of the Vietnamese people and "Eden in the East" by Oppenheimer]. Họp luu [Confluence] 64: 24-52. http://www.nhanvan.com:80/ magazines/hopluu/64/nguyenquangtrong_venguongoc.htm (accessed through the Wayback Machine on 11 December 2017).

Nguyễn, T. T. 2001. Việt Nam, trung tâm nông nghiệp lúa nước và công nghiệp đá, xưa nhất thế giới [Việt Nam, the oldest center of wet rice agriculture and stone industry in the world]. VietCatholic, 9 September. http://www.mevietnam.org/NguonGoc/ ntt-vanminhluanuoc.html (accessed 6 December 2017).

Nguyễn, V. T. 2001. Nhân đọc "Eden in the East": đặt lại vấn đề nguồn gốc dân tộc và văn minh Việt Nam [On reading "Eden in the East": Posing again the question of the origins of the Vietnamese people and civilization]. Tu tuơng 15 (August), 10-15. http://tutuong.hypermart.net/pdf files/TUTUONG15.pdf (accessed through the Wayback Machine on 1 November 2017).

. 2019. Nhân đọc 'Eden in the East': đặt lại vấn đề nguồn gốc dân tộc và văn minh Việt Nam" [On reading "Eden in the East": Posing again the question of the origins of the Vietnamese people and civilization]. Khoa Việt Nam học [Faculty of Vietnamese studies], 3 June. http://vns.edu.vn/index.php/vi/nghien-cuu/van-hoaviet-nam/1161-dat-lai-van-de-nguon-goc-dan-toc-va-van-minh-viet-nam (accessed 14 October 2019).

"Nguyễn Văn Tuấn.” n.d. Wikipedia. https://vi.wikipedia.org/wiki/Nguy\%E1\% B\%85n V\%C4\%83n Tu\%E1\%BA\%A5n_(gi\%C3\%A1o s\%C6\%B0 d $\%$ E1\%BB\%8Bch_t $\%$ E1\%BB\%85_h\%E1\%BB\%8Dc) (accessed 12 December 2017). 
Normile, D. 1997. Yangtze seen as earliest rice site. Science 275 (5298): 309, https://doi. org/10.1126/science.275.5298.309.

Oppenheimer, S. 1998. Eden in the East: The drowned continent of Southeast Asia. London: Weidenfeld and Nicolson.

. 2005. Địa đàng ở Phưong Đông: lịch sủ huy hoàng của lục địa Đông Nam Á bị chim [Eden in the East: The glorious history of the drowned continent of Southeast Asia]. Transl. Lê, S. G. and Hoàng, T. Ha, ed. Cao, X. P. Hanoi: Nhà xuất bản Lao động.

Phạm, Đ. T. 2017. Tái bản bộ sách triết lý an vi của Kim Định [The republication of the set of books on the tranquillity philosophy of Kim Định]. Zing.vn, 5 May. https://news. zing.vn/tai-ban-bo-sach-triet-ly-an-vi-cua-kim-dinh-post744323.html (accessed 29 April 2019).

Reich, D. et al. 2011. Denisova admixture and the first modern human dispersals into Southeast Asia and Oceania. The American Journal of Human Genetics 89 (4): 516-528, https://doi.org/10.1016/j.ajhg.2011.09.005.

Sauer, C. O. 1952. Agricultural origins and dispersals. New York: American Geographical Society.

Soares, P, et al. 2008. Climate change and postglacial human dispersals in Southeast Asia. Molecular Biology and Evolution 25 (6): 1209-1218, https://oi.org/10.1093/ molbev/msn068.

Solheim, W. G. II. 1967. Southeast Asia and the West. Science 157 (3791): 896-902. . 1971. New light on a forgotten past. National Geographic 139 (3): 330-339. . 1972. An earlier agricultural revolution. Scientific American 226 (4): 34-41. . 1996. Nusantao and the north-south dispersals. Indo-Pacific Prehistory Association Bulletin 2: 101-109.

. 1999. Thắp sáng lại quá khứ bị lãng quên [New light on a forgotten past]. Translated by Hoài Văn Tử and Vĩnh Như. Tư tương [Thought] 2 (May): 28-30. http://tutuong.hypermart.net/pdf/files/Tutuong2_extracts.pdf (accessed online through the Wayback Machine on 1 November 2017).

Spriggs, M. 2011. Archaeology and the Austronesian expansion: Where are we now? Antiquity 85 (328): 510-528, https://doi.org/10.1017/S0003598X00067910.

Stark, M. 2014. Dr. Wilhelm G. Solheim II (19 November 1924-25 July 2014): Appreciation. Antiquity Online. http://antiquity.ac.uk/tributes/solheim.html (accessed 21 November 2017).

Tạ, C. Đ. T. 2008. Về 'huyền sử gia' Kim Định và các chi, bàng phái 'huyền sử học' Việt Nam? [How about "obscure historian" Kim Định and the branches and factions of Vietnamese "obscure history studies?]. Talawas, 4 February, http://www.talawas. org/talaDB/suche.php?res=12188\&rb=0302 (accessed 28 April 2019).

Taylor, K. W. 1983. The birth of Vietnam. Berkeley: University of California Press. . 2013. A history of the Vietnamese. Cambridge: Cambridge University Press.

Ủy ban khoa học xã hội Việt Nam [Committee for Social Science Research of Vietnam]. 1971. Lịch sủ Việt Nam [History of Vietnam]. Hanoi: Khoa học xã hội.

"Văn minh lúa nước" [Wet rice civilization]. n.d. Wikipedia. https://vi.wikipedia.org/ wiki/V\%C4\%83n_minh_1\%C3\%BAa_n\%C6\%B0\%E1\%BB\%9Bc (accessed 19 December 2017). 
Vavilov, N. I. 1951. Phytogeographic basis of plant breeding. Chronica Botanica 13 (1/6): $13-54$.

Vo, T. S. 2002. Bs Nguyễn Thị Thanh: khoa học \& đức tin; phỏng vấn đặc biệt [Dr. Nguyễn Thị Thanh: Science and faith], 14 May, http://motgoctroi.com/StNguoiNViec/ BsNThiThanh_Ductin.htm (accessed through the Wayback Machine on 11 December 2017).

Vũ, K. T. 2012. Tọa đầm tưởng niệm cố triết gia Lương Kim Định nhân 15 năm ngày mất của ông [Symposium commemorating the late philosopher Lương Kim Định on the occasion of the fifteenth year since his passing]. Văn hóa học: Trung tâm văn hóa học lý luận và ứng dụng [Cultural studies: Centre of Theoretical and Applied Cultural Studies], 20 July, http://www.vanhoahoc.edu.vn/tin-tuc/tin-lienquan/2252-toa-dam-tuong-niem-co-triet-gia-luong-kim-dinh-nhan-15-nam-ngaymat-cua-ong.html (accessed 29 April 2019).

Wen, B. et al. 2004. Genetic evidence supports demic diffusion of Han culture. Nature 431: 302-305, https://doi.org/10.1038/nature02878.

Who's who in Vietnam, 3rd ed. 1974. Saigon: Vietnam Press.

Yen, D. E. 1980. The Southeast Asian foundations of oceanic agriculture: A reassessment. Journal de la Société des Océanistes 36 (66):140-147. 1982. Ban Chiang pottery and rice: A discussion of the inclusions in the pottery mix. Expedition 24 (4): 51-64. 